Article

\title{
Potential Range Expansion of Japanese Honeysuckle (Lonicera japonica Thunb.) in Southern U.S. Forestlands
}

\author{
Hsiao-Hsuan Wang ${ }^{1, *}$, Carissa L. Wonkka ${ }^{2}$, William E. Grant ${ }^{1}$ and William E. Rogers ${ }^{2}$ \\ 1 Department of Wildlife and Fisheries Sciences, Texas A\&M University, College Station, \\ TX 77843, USA; E-Mail: wegrant@tamu.edu \\ 2 Department of Ecosystem Science and Management, Texas A\&M University, College Station, \\ TX 77843, USA; E-Mails: cwonkka@gmail.com (C.L.W.); wer@tamu.edu (W.E.R.) \\ * Author to whom correspondence should be addressed; E-Mail: hsuan006@tamu.edu; \\ Tel.: +1-979-845-5702; Fax: +1-979-845-3786.
}

Received: 11 June 2012; in revised form: 25 June 2012 / Accepted: 20 July 2012 /

Published: 27 July 2012

\begin{abstract}
Japanese honeysuckle is one of the most aggressive invasive vines in forestlands of the southern United States. We analyzed field data collected by the U.S. Forest Service to identify potential determinants of invasion and to predict likelihood of further invasion under a variety of possible management strategies. Results of logistic regression, which classified $74 \%$ of the field plots correctly with regard to species presence and absence, indicated probability of invasion is correlated positively with adjacency to water bodies, temperature, site productivity, species diversity, and private land ownership, and is correlated negatively with slope, stand age, artificial regeneration, distance to the nearest road, and fire disturbance. Habitats most at risk to further invasion under current conditions occur throughout Mississippi, stretching northward across western Tennessee and western Kentucky, westward across southern Arkansas, eastward across north-central Alabama, and also occur in several counties scattered within Virginia. Invasion likelihoods could be increased by global climate change and reduced most by conversion to public land ownership, followed by artificial regeneration, and fire disturbance. While conversion of land ownership may not be feasible, this result suggests the opportunity for decreasing the likelihood of invasions on private lands via using selected management practices.
\end{abstract}

Keywords: biodiversity; biological invasions; habitat quality; invasive species; multiple logistic regression 


\section{Introduction}

Biotic invasion has become a critical issue in most ecosystems word-wide. Non-native species invasions can lead to numerous adverse consequences for native systems. Invasion can modify ecological properties, processes, and functions [1]. Invasive plants can compete with native species for resources, disrupt evolutionary processes and hybridize with natives, reduce system productivity, alter disturbance regimes, and threaten native biodiversity [1-5]. Additionally, invasive species can impose large economic costs, through loss of economic output and the cost of control [6-8]. The threat of invasion continues to increase due to globalization, world transport and travel, and climate change [9-12].

Invasion in southeastern U.S. forestlands poses a severe threat to an ecologically and economically important region. Southeastern forests contain over 200 million acres of timberland, providing $62 \%$ of U.S. timber production and over $15 \%$ of world-wide timber [13,14]. Invasive plants threaten the continued productivity of important hardwood and softwood species which is essential to the economic sustainability of the region [15]. In addition, Southeastern U.S. forests contain a high level of native biodiversity, with over 3000 plant species [16-18], and provide many other important ecosystem services.

Japanese honeysuckle (Lonicera japonica Thunb.), a perennial woody vine, is one of the more ubiquitous and aggressively invasive pests of southeastern U.S. forests. Although introduced in the early 1800s, L. japonica was first recorded outside of cultivation along the Potomac River in 1882 [19]. Numerous different cultivars have subsequently been introduced and it has presently become naturalized in 45 states of the U.S. and the Canadian province of Ontario [20,21]. L. japonica has many characteristics which make it a successful invader. It experiences rapid growth [22], phenotypic plasticity for response to herbivore damage, leaf phenology, and plant growth form and structure [23,24], evergreen or semi-evergreen leaves, and early flowering for long durations [22]. Additionally, it can reproduce vegetatively or through seed, and is accessible to a wide diversity of pollinators (both diurnal and nocturnal due to dusk flower opening). It exploits light gaps efficiently [23] and can resprout from the roots following disturbance $[25,26]$.

L. japonica is found in most southeastern forest communities and can have negative effects on the native vegetation of the communities in which it is prevalent [27]. It has been shown to decrease diversity [28-30], modify vegetation structure [31], and inhibit growth and reproduction of native species under certain circumstances [32-34]. There are currently no predators or pathogens in the introduced range which have significant detrimental effects on L. japonica [20], and eradication from an area requires constant intensive combinations of removal strategies [20,31].

Although already wide-spread, L. japonica continues to expand its range in North America and invade formerly intact areas within its established range [20]. The frequency of these occurrences is likely to increase with increased temperatures [35-37] and additional disturbances [38,39]. Reliable predictions of habitats at risk are needed in order to enact preventative measures for controlling the spread of L. japonica. In this paper, we apply logistic regression to analyze an extensive data set collected as part of the Forest Inventory and Analysis (FIA) program of the U.S. Forest Service. We aim to identify potential determinants of invasion and predict the likelihood of further invasion under a variety of possible management strategies. 


\section{Experimental Section}

\subsection{Study Area and Data Sources}

This study area is the southern United States, one of the most productive forest regions in the country and the world [40]. Hence, the U.S. Forest Service's Southern Research Station of the U.S. Department of Agriculture (USDA) Forest Service's Forest Inventory and Analysis (FIA) started conducting a national forest resource survey that provides a means of studying the problem of plant invasions in forest land in early 2000 [41]. The invasive plant survey supplements traditional forest resource inventories on a $5-\mathrm{km}$ grid and located on forest land in the 13 southern states by federal and state forest resource survey crews [41]. The survey is constructed on a state-by-state basis with a plan to survey one-fifth of each state's plots annually, and thereafter on a continuing cycle. At present, preliminary analyses for frequency and severity of invasion by L. japonica are available for twelve states, including Alabama, Arkansas, Florida, Georgia, Kentucky, Louisiana, Mississippi, North Carolina, South Carolina, Tennessee, east Texas (eastern portion only), and Virginia, while surveys have not yet started in Oklahoma (Figure 1). Hence, we used these twelve states as our study area. We drew data from two U.S. Forest Service Southern Region FIA datasets: (1) we drew upon the Nonnative Invasive Plants dataset to obtain the presence of L. japonica in all plots; and (2) we drew upon the traditional FIA dataset to obtain data on stand characteristics, site conditions, and management activities and disturbances [42,43]. We also obtained climatic data from NOAA Satellite and Information Service [44]. We linked data from these three sets using the FIA plot identification numbers and locations.

Figure 1. Current occupation of forestlands in the southern United States by L. japonica [42,43]. Gray and black dots represent absence and presence on U.S. Forest Service plots of Japanese honeysuckle, respectively.

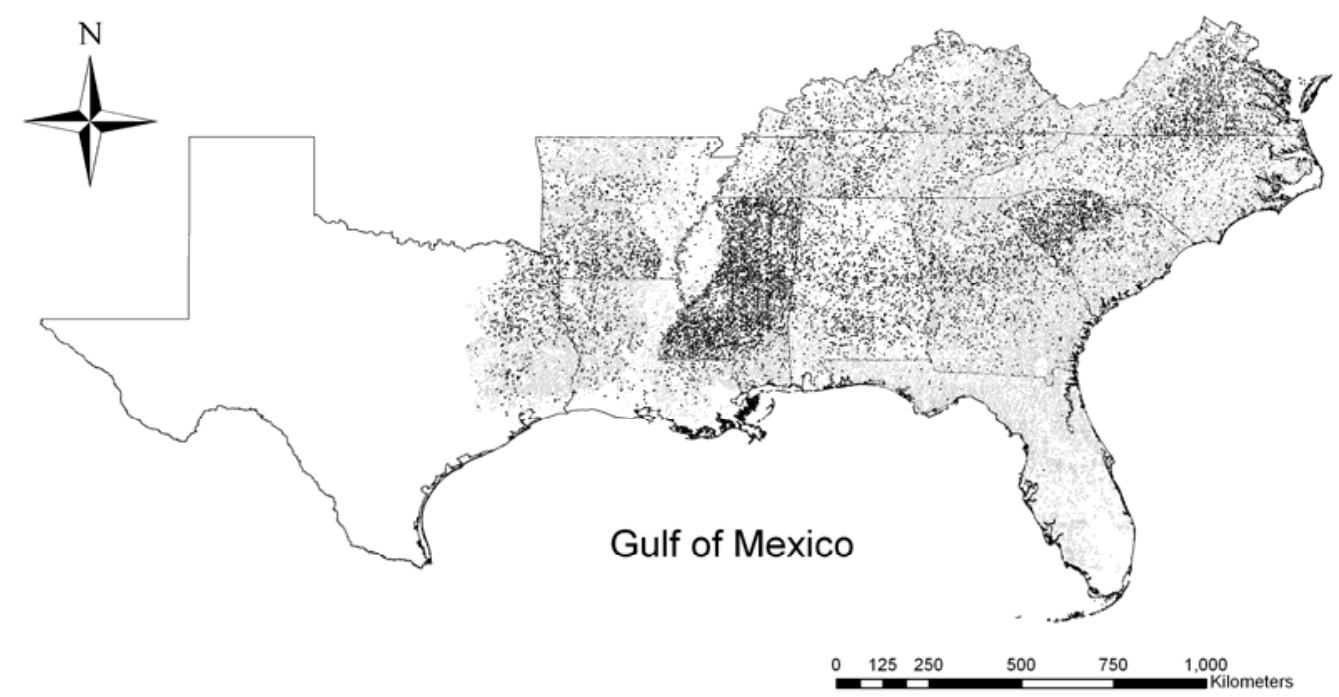

\subsection{Potential Predictors of Invasion}

This study identified, from existing literature, potential explanatory variables that might have promoted the invasion of L. japonica in the southern U.S. Previous work has identified several predictors of plant invasions, including landscape features such as elevation, slope, adjacency to water 
bodies [45-47], climatic conditions such as extreme minimum and maximum temperature [48], forest and site condition such as stand age, site productivity, and species diversity [49-51], forest management activities and disturbances such as timber harvest, site preparation, artificial regeneration, natural regeneration, distance to the nearest road, insect damage, disease damage, fire damage, animal damage, and wind damage [52,53]. Drawing on the literature on plant invasions, we selected a set of possible variables for plots within our study area directly from the traditional FIA dataset (Table 1). In addition, we used plot Universal Transverse Mercator (UTM) coordinates, $x$ for distance east and $y$ for distance north of the UTM origin, to test for spatial autocorrelation effects across plots, employing Moran's $I$ index [54]. We also used the same dataset to compute Shannon's index of tree species diversity, $H_{s}$, for each plot $[49,50]$ :

$$
H_{s}=-\sum_{i=1}^{n_{s}} \frac{B_{i}}{B} \ln \left(\frac{B_{i}}{B}\right)
$$

where $B$ and $B_{i}$ are the total stand basal area and the basal area of trees of species $i$, respectively, and $n_{s}$ is the number of tree species.

Table 1. Descriptions, values or units of measure, and means or frequencies of landscape features, forest conditions, and management activities and disturbances evaluated as potential determinants of site invasion by L. japonica on forested plots in the southern United States.

\begin{tabular}{|c|c|c|}
\hline Variable description & Value or unit of measure & Mean (range) or frequency \\
\hline \multicolumn{3}{|l|}{ Landscape features } \\
\hline Elevation & $\mathrm{m}$ & $139(-36 \sim 1524)^{a}$ \\
\hline Slope & degree & $5.39(0 \sim 77.5)^{\mathrm{a}}$ \\
\hline \multirow[t]{2}{*}{ Adjacency to water bodies within $300 \mathrm{~m}$} & $0:$ no & $0: 27,940$ \\
\hline & $1:$ yes & $1: 6,731$ \\
\hline$x$ & $\begin{array}{l}\text { Easting of plot UTM } \\
\text { coordinates }(\mathrm{m})\end{array}$ & $\begin{array}{c}3.62 \times 10^{5} \\
\left(2.29 \times 10^{5} \sim 5.28 \times 10^{5}\right)^{\mathrm{a}}\end{array}$ \\
\hline$y$ & $\begin{array}{l}\text { Northing of plot UTM } \\
\text { coordinates }(\mathrm{m})\end{array}$ & $\begin{array}{c}3.75 \times 10^{6} \\
\left(2.72 \times 10^{6} \sim 4.36 \times 10^{6}\right)^{a}\end{array}$ \\
\hline \multicolumn{3}{|l|}{ Climatic conditions } \\
\hline Mean daily minimum temperature & ${ }^{\circ} \mathrm{C}$ & $8.44(-6.61 \sim 21.11)^{\mathrm{a}}$ \\
\hline Mean daily maximum temperature & ${ }^{\circ} \mathrm{C}$ & $28.28(21.17 \sim 29.44)^{\mathrm{a}}$ \\
\hline \multicolumn{3}{|l|}{ Forest conditions } \\
\hline Stand age & years & $44.27(1 \sim 184)^{\mathrm{a}}$ \\
\hline \multirow{7}{*}{$\begin{array}{l}\text { Site productivity } \\
\text { (height-age curve categories) }\end{array}$} & 1:0-1.39 & 1: 139 \\
\hline & 2: $1.40-3.49$ & 2: 5,912 \\
\hline & $3: 3.50-5.94$ & 3: 17,270 \\
\hline & $4: 5.95-8.39$ & 4: 12,112 \\
\hline & $5: 8.40-11.54$ & $5: 5,609$ \\
\hline & $6: 11.55-15.74$ & $6: 1,483$ \\
\hline & $7:>15.74 \mathrm{~m}^{3} / \mathrm{ha} / \mathrm{yr}$ & 7: 112 \\
\hline Species diversity & Shannon's species diversity & $1.48(0 \sim 3.02)^{\mathrm{a}}$ \\
\hline
\end{tabular}


Table 1. Cont.

\begin{tabular}{|c|c|c|}
\hline Variable description & Value or unit of measure & Mean (range) or frequency \\
\hline \multicolumn{3}{|l|}{$\begin{array}{l}\text { Management activities } \\
\text { and disturbances }\end{array}$} \\
\hline Timber harvest ${ }^{\mathrm{b}}$ & $\begin{array}{l}0: \text { no } \\
1: \text { yes }\end{array}$ & $\begin{array}{c}0: 36,216 \\
1: 6,421\end{array}$ \\
\hline Site preparation ${ }^{\mathrm{b}}$ & $\begin{array}{l}0: \text { no } \\
1: \text { yes }\end{array}$ & $\begin{array}{l}0: 41,181 \\
1: 1,456\end{array}$ \\
\hline Artificial regeneration ${ }^{b}$ & $\begin{array}{l}0: \text { no } \\
1: \text { yes }\end{array}$ & $\begin{array}{l}0: 31,545 \\
1: 11,092\end{array}$ \\
\hline Natural regeneration ${ }^{b}$ & $\begin{array}{l}0: \text { no } \\
1: \text { yes }\end{array}$ & $\begin{array}{c}0: 41,663 \\
1: 974\end{array}$ \\
\hline Distance to the nearest road & $\begin{array}{c}1:<30 \\
2: 30-91 \\
3: 91-152 \\
4: 152-305 \\
5: 305-805 \\
6: 805-1,609 \\
7: 1,609-4,828 \\
8: 4,828-8,047 \\
9:>8047 \mathrm{~m}\end{array}$ & $\begin{array}{c}1: 2,846 \\
2: 4,732 \\
3: 4,218 \\
4: 7,409 \\
5: 10,424 \\
6: 4,339 \\
7: 1,349 \\
8: 119 \\
9: 84\end{array}$ \\
\hline Insect disturbance $^{\mathrm{b}}$ & $\begin{array}{l}0: \text { no } \\
1: \text { yes }\end{array}$ & $\begin{array}{c}0: 42,271 \\
1: 366\end{array}$ \\
\hline Disease disturbance $^{\mathrm{b}}$ & $\begin{array}{l}0: \text { no } \\
1: \text { yes }\end{array}$ & $\begin{array}{l}0: 42,480 \\
1: 157\end{array}$ \\
\hline Fire disturbance ${ }^{\mathrm{b}}$ & $\begin{array}{l}0: \text { no } \\
1: \text { yes }\end{array}$ & $\begin{array}{l}0: 41,551 \\
1: 1,086\end{array}$ \\
\hline Animal disturbance ${ }^{\mathrm{b}}$ & $\begin{array}{l}0: \text { no } \\
1: \text { yes }\end{array}$ & $\begin{array}{l}0: 42,069 \\
1: 568\end{array}$ \\
\hline $\begin{array}{l}\text { Wind disturbance } \\
\text { (including hurricanes and tornados) }\end{array}$ & $\begin{array}{l}0: \text { no } \\
1: \text { yes }\end{array}$ & $\begin{array}{c}0: 41,269 \\
1: 1,368\end{array}$ \\
\hline \multicolumn{3}{|l|}{ Ownership } \\
\hline Forestland ownership & $\begin{array}{l}0 \text { : public } \\
\text { 1: private }\end{array}$ & $\begin{array}{c}0: 5,349 \\
1: 37,288\end{array}$ \\
\hline
\end{tabular}

\footnotetext{
${ }^{a}$ : Numbers inside the parentheses are the range of the variable; ${ }^{b}$ : Nominally within the past 5 years. With damage codes, at least $25 \%$ of the trees in a stand must be damaged to warrant a code of 1 .
}

We evaluated all potential determinants of invasion via stepwise multiple logistic regression, using a backwards elimination procedure [55]:

$$
\operatorname{logit}(p)=\log \left(\frac{p}{1-p}\right)=a+X^{\prime} \beta
$$

where $p$ is the probability of presence of invasion by $L$. japonica, $p /(1-p)$ is the odds of the presence of L. japonica, $X$ is the vector of independent variables which are shown in Table 1 , and $\alpha$ and $\beta$ (a vector) are the regression coefficients. We tested for zero inflation using zero-inflated binomial regression [56]. When we ran multiple logistic regression, we removed insignificant terms and 
re-estimated the model [57,58] until the Akaike information criterion (AIC) [59] could not be lowered further. We then used Hosmer-Lemeshow's test to check for goodness-of-fit [60]. We re-estimated the last model obtained in this way, assuming a random error, to assess the significance of the spatial autocorrelation of the residuals. We conducted all statistical analyses using SAS 9.2 (SAS Institute Inc., 2008).

\subsection{Likelihood of Further Invasion}

Based on regression results, we estimated the probability of presence of invasion of each forested plot as:

$$
p=\frac{\exp \left[\alpha+X^{\prime} \beta\right]}{1+\exp \left[\alpha+X^{\prime} \beta\right]}
$$

We then superimposed these probabilities of occupancy on a map of the study area using ArcMap $^{\mathrm{TM}} 9.1$ (ESRI, Redlands, CA, USA). To provide a more useful management perspective, we also generated a map indicating the average probability for each county. We explored effects of climate changes and some possible effects of different management strategies on the likelihood of further invasion by assuming global climate change $\left(2{ }^{\circ} \mathrm{C}\right.$ warming $)$ and the occurrence of artificial regeneration, fire disturbance, and complete conversion to public land ownership in each county within the study area (i.e., we assigned different values to the elements of the vector, $X$, of independent variables in Equation 3).

\section{Results}

\subsection{Potential Determinants of Invasion}

Results of logistic regression indicated a positive correlation between likelihood of invasion and adjacency (within $300 \mathrm{~m}$ ) to water bodies, mean daily maximum temperature, site productivity, species diversity, and private land ownership, and a negative correlation between invasion likelihood and slope, stand age, artificial regeneration, distance to the nearest road, and fire disturbance (Table 2). The model classified $74 \%$ of the plots correctly with regard to species presence and absence, and Hosmer and Lemeshow's goodness-of-fit test indicated no significant difference $(p=0.24)$ between observed and model-predicted occupancy values. The coefficient of zero inflation for the final logistic regression model was not significant $(p>0.05)$, and the AIC of the zero-inflated binomial model $(24,454)$ was significantly larger than the AIC of the multiple logistic regression model $(22,702)$. Moran's $I$ index $(I=0.04)$ indicated no statistically significant $(p=0.19)$ spatial autocorrelation at the $5 \%$ significance level. (We excluded 7,966 of the 42,637 plots because of missing data). 
Table 2. Potential determinants of L. japonica invasion of forested plots in the southern United States as indicated by results of stepwise multiple logistic regression.

\begin{tabular}{|c|c|c|c|c|c|}
\hline \multirow{2}{*}{ Variable } & \multirow{2}{*}{$\begin{array}{l}\text { Estimated } \\
\text { coefficient }\end{array}$} & \multirow{2}{*}{$\begin{array}{c}\text { Estimated } \\
\text { standard error }\end{array}$} & \multirow{2}{*}{$\begin{array}{l}\text { Estimated } \\
\text { odds ratio }^{\text {a }}\end{array}$} & \multicolumn{2}{|c|}{$\begin{array}{l}95 \% \text { confidence intervals } \\
\text { for the odds ratio }\end{array}$} \\
\hline & & & & Lower & Upper \\
\hline \multicolumn{6}{|c|}{ Landscape features } \\
\hline Slope & -0.0219 & 0.0021 & 0.978 & 0.974 & 0.982 \\
\hline Adjacency to water bodies within $300 \mathrm{~m}$ & 0.1604 & 0.0327 & 1.174 & 1.101 & 1.252 \\
\hline \multicolumn{6}{|c|}{ Climatic conditions } \\
\hline Mean daily maximum temperature & 0.4626 & 0.0353 & 1.588 & 1.482 & 1.702 \\
\hline \multicolumn{6}{|c|}{ Forest conditions } \\
\hline Stand age & -0.0144 & 0.0006 & 0.986 & 0.985 & 0.987 \\
\hline Site productivity & 0.2435 & 0.0127 & 1.276 & 1.244 & 2.308 \\
\hline Species diversity & 0.3340 & 0.0222 & 1.397 & 1.337 & 1.459 \\
\hline \multicolumn{6}{|c|}{ Management activities and disturbances } \\
\hline Artificial regeneration & -0.5511 & 0.0686 & 0.576 & 0.504 & 0.659 \\
\hline Distance to the nearest road & -0.0653 & 0.0080 & 0.937 & 0.922 & 0.952 \\
\hline Fire disturbance & -0.3494 & 0.0880 & 0.705 & 0.593 & 0.838 \\
\hline \multicolumn{6}{|c|}{ Ownership } \\
\hline Forestland ownership & 0.7814 & 0.0481 & 2.185 & 1.988 & 2.401 \\
\hline Constant & -2.5040 & 0.2463 & - & - & - \\
\hline
\end{tabular}

\footnotetext{
a: The estimated odds ratio indicates the change in the probability of invasion by L. japonica that would result from a one-unit change in the value of the indicated variable. For example, a one-unit increase in site productivity signifies that invasion is 1.276 times more likely than before, after controlling for the other variables.
}

\subsection{Likelihood of Further Invasion}

\subsubsection{Under Current Conditions}

Estimated probabilities of further invasion $(p)$ were relatively low, with approximately $69 \%$ $(\approx 72$ million ha) of the plots falling within the $0<p \leq 0.4$ category, $16 \%(\approx 17$ million ha) within the $0.4<p \leq 0.6$ category, and $5 \%(\approx 5$ million ha) within the $0.6<p \leq 0.8$ category. About $10 \%$ ( $\approx 10$ million ha) of the plots fell within the $p>0.8$ category, the majority (22\%) of which were located in Mississippi (Figure 2(a)). On a county by county basis, higher average estimated probabilities $\left(p^{\prime}>0.4\right)$ appeared throughout Mississippi, stretching northward across western Tennessee and western Kentucky, westward across southern Arkansas, eastward across north-central Alabama, and also appeared in several counties scattered within Virginia; the six counties with highest average probabilities $\left(0.8<p^{\prime} \leq 1.0\right)$ were all located in Mississippi (Figure 2(a)). 
Figure 2. Estimated probability of occupancy of forestlands in each U.S. Forest Service plot (left) and average estimated probability in each county (right) in the southern United States by L. japonica with (a) no management; (b) global climate change; (c) public ownership; (d) artificial regeneration; and (e) fire disturbance.
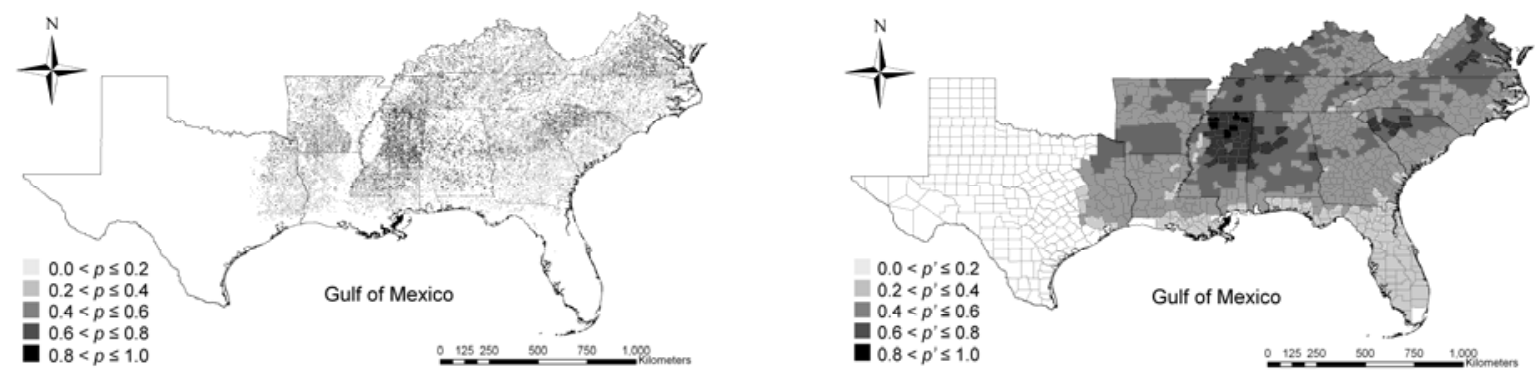

(a)
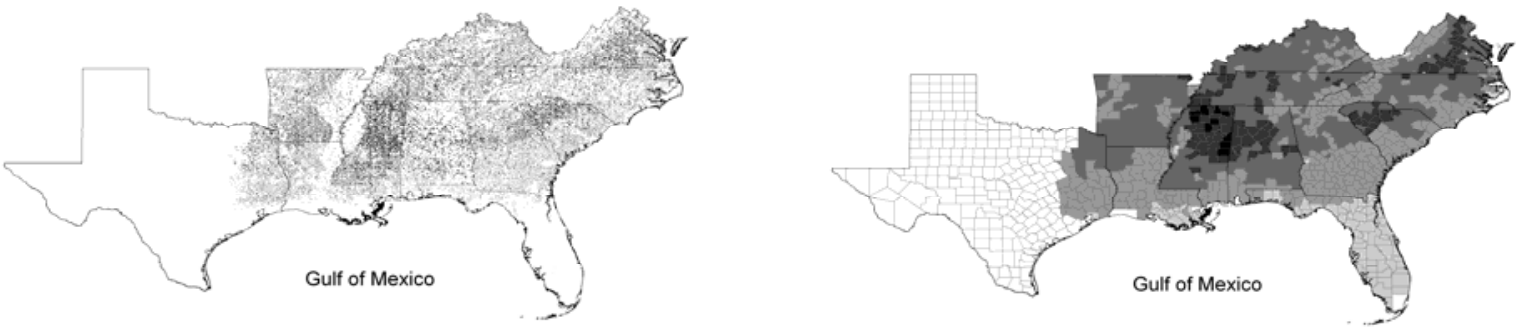

(b)
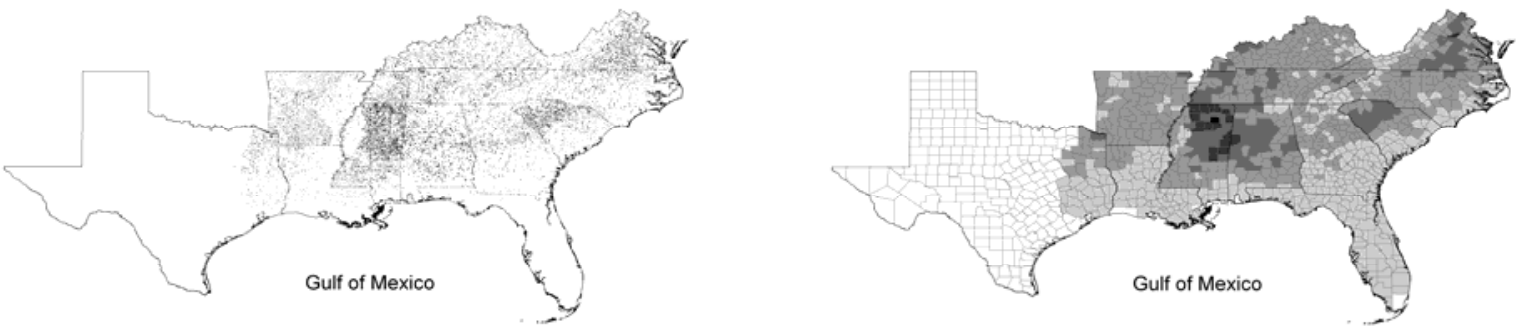

(c)
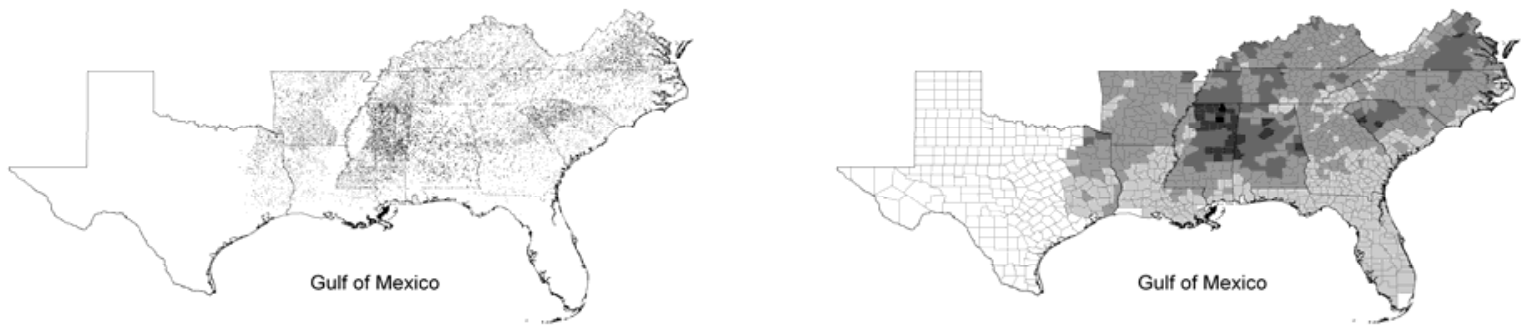

(d)
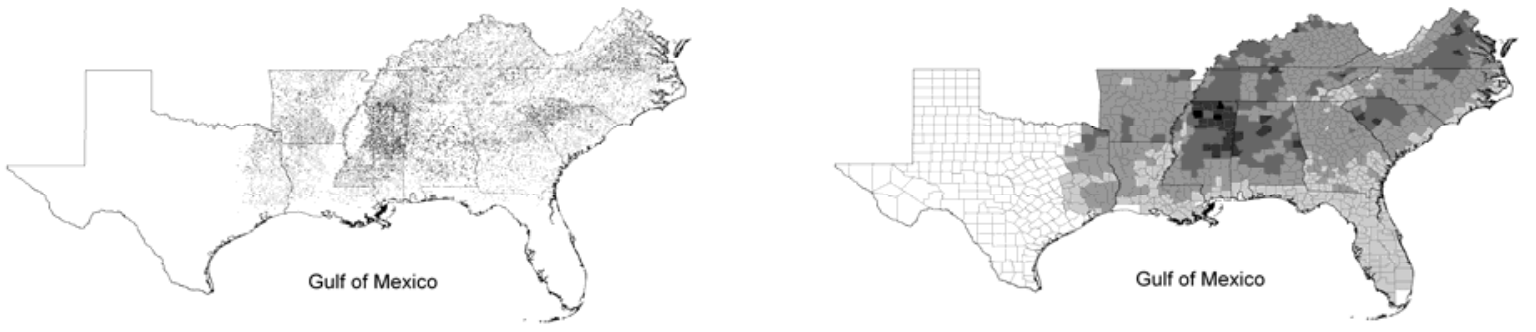

(e) 
Figure 3. Number of counties within the indicated average estimated probability ( $\left.p^{\prime}\right)$ range for invasion with no management, global climate change, conversion to public ownership, artificial regeneration, and fire disturbance.

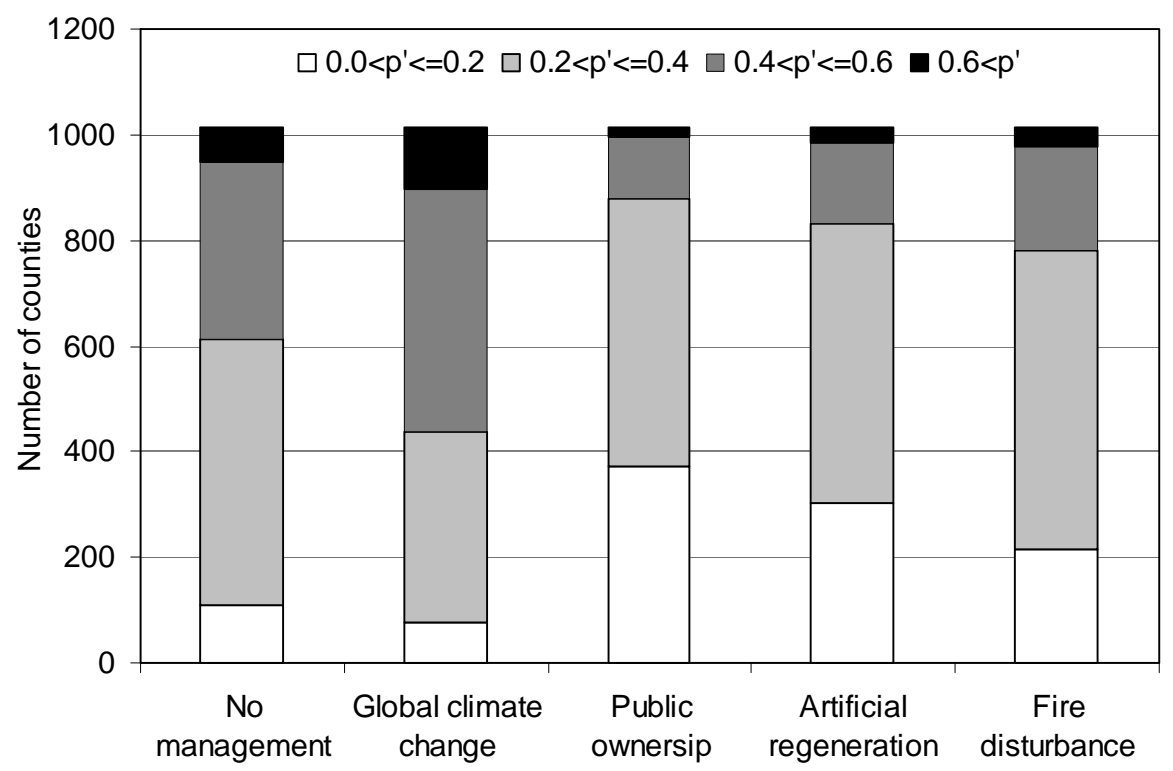

\subsubsection{Under Global Climate Change and Alternative Management Strategy}

Global temperature is likely to rise during the upcoming decades as predicted by the Intergovernmental Panel on Climate Change [61]. Using our model, global climate change with a $2{ }^{\circ} \mathrm{C}$ warming increased overall $p$ ' from 0.37 to 0.43 and increased the number of counties with $p^{\prime}>0.6$ from 68 to 116 , with $p^{\prime}$ increasing from 0.52 to 0.57 in Mississippi where invasion probabilities were highest (Figures 2 (b) and 3 ).

Average estimated probabilities of further invasion $\left(p^{\prime}\right)$ were reduced the most by conversion to public land ownership, followed by artificial regeneration and fire disturbance (Figure 2). Conversion to public land ownership decreased overall $p$ ' from 0.37 to 0.26 and decreased the number of counties with $p^{\prime}>0.6$ from 68 to 20 , with counties having $p^{\prime}>0.60$ disappearing from South Carolina, Tennessee, and Virginia (Figures 2(c) and 3). Artificial regeneration decreased overall $p$ ' from 0.37 to 0.28 and decreased the number of counties with $p^{\prime}>0.6$ from 68 to 30 (Figures 2(d) and 3). Fire disturbance decreased overall $p$ ' from 0.37 to 0.31 and decreased the number of counties with $p^{\prime}>0.6$ from 68 to 37 (Figures 2(e) and 3).

\section{Discussion}

Environmental niche models which include current distribution and land use parameters can be valuable tools for predicting the future spread of L. japonica. Although L. japonica is naturalized and found in most habitat types in southeastern U.S. forests [20], it is still spreading into uninvaded areas possessing suitable environmental conditions $[62,63]$. Predicting the likelihood of invasion into a given area will allow managers to focus prevention measures on high risk and environmentally sensitive areas. Additionally, correlation determinations between occurrence and management can assist managers in choosing appropriate strategies for minimizing risk in areas environmentally suited to 
further L. japonica invasion. Our modeling analysis suggests that while L. japonica distribution is ultimately driven by a suite of environmental characteristics, certain management strategies might be effective for preventing its spread.

Suitable environmental characteristics are the dominant correlates with L. japonica occurrence, but anthropogenic features and land use/management variables also showed strong negative and positive correlations with potential invasion. Proximity to water bodies, daily maximum temperatures, and site productivity were all strongly positively correlated environmental variables. Climate is one of the primary determinants of species range [64] and invasion is frequently found to be highest in climatically suitable areas [65]. However, climate alone is not sufficient to determine a species' invasion potential [66]. Stand age, artificial forest regeneration, and fire disturbance are negatively correlated, whereas private land ownership is positively correlated with probability of invasion, suggesting that land management activities contribute substantially to successful invasions.

Artificial regeneration, while expensive, can decrease the risk of L. japonica invasion. This might be an important consideration in areas at high risk, given the potential economic losses attendant to L. japonica invasion. L. japonica, like other invasive vines, can inhibit growth of host species through light interception and even kill host species through girdling [67]. L. japonica has been shown to inhibit reproduction and growth of non-host trees through root competition around forest edges [34]. In addition, L. japonica can indirectly inhibit growth of native species through site occupation and seedling suppression $[30,33,68]$. These negative effects manifest themselves as lost profits in forests managed for timber. Additionally, extensive and oftentimes cost prohibitive measures are required to eradicate L. japonica once established. With artificial regeneration following timber harvest, stands are intensively managed for desirable species, which maintains conditions that are more appropriate for the native desired species and less appropriate for L. japonica [69]. This usually includes site preparation through root-raking and burning or disking [70] which reduces likelihood of L. japonica establishment into the newly created forest gap. This removal of non-desirable species and subsequent rapid stand growth can inhibit the establishment of $L$. japonica into a newly formed forest gap, which is otherwise highly at risk for invasion given the aggressive exploitation of light gaps and rapid growth under high light conditions exhibited by L. japonica [23,32]. Intense disturbance can create favorable habitat for L. japonica [71]. However, planting native species and subsequent management for those species reduces the opportunity for L. japonica spread. Also, the resulting single-aged stand has lower potential for future small gap dynamics which L. japonica might exploit, given that most of the trees will survive to harvestable age and L. japonica invasion is severely restricted in closed canopy conditions [72].

While fire alone has not been an effective restoration technique for the eradication of L. japonica from an invaded area, our model showed that the probability of invasion is negatively correlated with fire disturbance, suggesting that prescribed burning might be an important tool in reducing the spread of L. japonica into uninvaded forests. Fire alone can reduce above-ground L. japonica density temporarily, but it readily resprouts from the roots allowing it to rapidly replace damaged tissues following a typical prescribed fire [26,28,73], although repeated fires and high intensity fire have been shown to reduce overall L. japonica abundance in several studies [74-76]. Management of uninvaded areas with prescribed fires can decrease the likelihood of invasion. Fire eliminates vegetative spread from invaded areas to surrounding forests. Additionally, prescribed burning can cause mortality in 
newly established seedlings of resprouting woody plants because the young plants have not had time to establish carbon reserves sufficient to allow root sprouting and the loss of photosynthetic tissues can lead to subsequent carbon starvation if reserves are low enough at the time of burning [77,78]. This is corroborated by West et al. [24] who determined that L. japonica can be suppressed by fire after observing higher L. japonica abundance in areas of high litter cover associated with escape from fire and Brewer and Menzel [76], who found that a combination of thinning and frequent burning reduces $L$. japonica abundance.

Several land-use features are also correlative indicators of potential distribution. We included land-use features in our model because current and past land-use has been shown to affect the distribution and abundance of many invasive plants [79,80]. Additionally, Surrette and Brewer determined that land use changes can actually create habitat suitable for L. japonica which disfavors native vegetation, leading to an increase in the abundance of the invader relative to native species [71]. Distance to the nearest road is negatively correlated with occurrence. Roads can act as invasion corridors facilitating the spread of invasive plants. This is especially likely for an invasive vine such as L. japonica which rapidly grows vegetatively in light gaps (like those created along roadways). This growth is facilitated by the dual growth forms characteristic of many vine species [19]. Where there is no existing structure for twining, L. japonica can grow in a mat form along the ground, increasing the likelihood that roads could act as corridors for, rather than barriers to, spread. Additionally, L. japonica is an important forage species for wildlife and was cultivated for planting [81]. Most plantings likely occur close to human populations which are usually located near roads, so increased invasion along roadways was likely facilitated by cultivation in areas near roads and along roads themselves. This is corroborated by other studies which show increased L. japonica invasion in areas of higher human population [21]. Indeed, Pysek et al. [82] present evidence suggesting a strong relationship between human distributions and invasive plants generally. We also found a highly positive correlation between private land ownership and invasion potential. This is likely the result of more intensive and expensive forest management occurring on public land, but could also be a result of more recent cultivation on private lands for wildlife forage, and potential size differences in forest parcels owned publically and privately. The smaller parcels owned by private landowners are more susceptible to invasion due to the fragmentation issues noted above. Baars et al. [83] found a higher threat of invasion in smaller forest remnants with smaller interior areas than in larger tracts with less edge relative to interior forest. While converting areas to public ownership is not a feasible management option for the prevention of L. japonica invasion, understanding the differences in management that lead to the higher invasion probabilities for publically owned lands can assist in the development of management recommendations for private landowners, which, if followed, could help avoid further spread of L. japonica on private lands without a switch in ownership.

In addition to looking at current climatic and environmental correlates of invasion potential and exploring management effects on risk of invasion, we investigated the potential for climate change to alter the invasive potential of $L$. japonica. In general, climate change and its attendant habitat alterations can facilitate spread and increased abundance of invasive species [84,85] and lead to changes in spatial patterns of invasive distribution [86]. While temperature effects on L. japonica have not been experimentally explored, an increase in overall global temperatures would yield an expected increase in the area of climatically suitable habitat for L. japonica. In addition, our model showed an 
increase in overall risk of invasion, and an increase in the area of highest risk, with a $2{ }^{\circ} \mathrm{C}$ increase in annual temperature, resulting from the strong positive correlation between annual maximum temperature and invasion potential. This suggests that not only will the potential range of L. japonica increase with climate change, but the likelihood of invasion increases within the existing range distribution. This information is important for forest managers in areas with currently low invasion probabilities that might increase with climate change in the future.

While niche models such as ours are useful for determining invasion potentials for large areas, there are some shortcomings of this modeling approach. First, our model is based on current presence and absence data, which might not represent the entire potential niche of the species, since invasion is an ongoing process $[66,87]$ and adaptation of L. japonica to its new environment may expand its potential niche [88]. Second, we modeled several potential drivers of invasion only implicitly. We included biotic interactions implicitly via inclusion of diversity and productivity correlates of $L$. japonica occurrence, but particular species interactions likely help shape the invasion process [89].

Nonetheless, we feel our model offers important insights into the management of L. japonica, which threatens to continue its invasion throughout southeastern U.S. forests, as well as other, recently invaded, areas [90]. Armed with knowledge of current and potential future high risk areas and, hence, likely paths of invasion, forest managers can develop long term monitoring and control strategies for effectively slowing range expansion and mitigating its effects.

\section{Conflict of Interest}

The authors declare no conflict of interest.

\section{References}

1. Mack, R.N.; Simberloff, D.; Lonsdale, W.M.; Evans, H.; Clout, M.; Bazzaz, F.A. Biotic invasions: Causes, epidemiology, global consequences, and control. Ecol. Appl. 2000, 10, 689-710.

2. Rhymer, J.M.; Simberloff, D. Extinction by hybridization and introgression. Annu. Rev. Ecol. Syst. 1996, 27, 83-109.

3. Vitousek, P.M.; D’Antonio, C.M.; Loope, L.L.; Westbrooks, R. Biological invasions as global environmental change. Am. Sci. 1996, 84, 468-478.

4. Walker, B.H.; Steffen, W. An overview of the implications of global change for natural and managed terrestrial ecosystems. Conserv. Ecol. 1997, 1, 2.

5. Lodge, D.M.; Williams, S.; MacIsaac, H.J.; Hayes, K.R.; Leung, B.; Reichard, S.; Mack, R.N.; Moyle, P.B.; Smith, M.; Andow, D.A.; et al. Biological invasions: Recommendations for U.S. policy and management. Ecol. Appl. 2006, 16, 2035-2054.

6. Sandlund, O.T.; Schei, P.J.; Viken, Å. Invasive Species and Biodiversity Management; Kluwer Academic Publishers: Dordrecht, The Netherlands, 2001; p. 437.

7. Pimentel, D. Environmental and economic costs of the application of pesticides primarily in the United States. Environ. Dev. Sustain. 2005, 2, 229-252. 
8. McNeely, J.A. Human Dimensions of Invasive Alien Species. In Invasive Alien Species: A New Synthesis; Mooney, H.A., Mack, R.N., McNeely, J.A., Neville, L.E., Schei, P.J., Waage, J.K., Eds.; Island Press: Washington, DC, USA, 2005; pp. 285-309.

9. Henderson, L.; Wells, M.J. Alien Plant Invasions in the Grassland and Savanna Biomes. In The Ecology and Management of Biological Invasions in Southern Africa; Macdonald, I.A.W., Kruger, F.J., Ferrar, A.A., Eds.; Oxford Univeristy Press: Capetown, South Africa, 1986; pp. 109-117.

10. Di Castri, F. History of Biological Invasions with Special Emphasis on the Old World. In Biological Invasions: A Global Perspective; Drake, J., di Castri, F., Groves, R., Kruger, F., Mooney, H.A., Rejmanek, M., Williamson, M., Eds.; Wiley: New York, NY, USA, 1989; pp. 1-30.

11. Simberloff, D. Global climate change and introduced species in United States forests. Sci. Total Environ. 2000, 262, 253-261.

12. McAusland, C.; Costello, C. Avoiding invasives: Trade-related policies for controlling unintentional exotic species introductions. J. Environ. Econ. Manag. 2004, 48, 954-977.

13. McNulty, S.G.; Moore, J.A.; Iverson, L.; Prasad, A.; Abt, R.; Smith, B.; Sun, G.; Gavazzi, M.; Bartlett, J.; Murray, B.; et al. Application of linked regional scale growth, biogeography, and economic models for southeastern united states pine forests. World Resour. Rev. 2000, 12, 298-320.

14. USDA. The Forest Inventory and Analysis Database: Database Description and Users Manual Version 5.1; U.S. Department of Agriculture Forest Service: Arlington, VA, USA, 2011.

15. Hayes, D. Earth day 1990: Threshold of the green decade. World Policy J. 1990, 7, 289-304.

16. Skeen, J.N.; Doerr, P.D.; Lear, D.H.V.; van Lear, D.H.; Quarterman, E.; Burbanck, M.P.; Shure, D.J.; DeSelm, H.R.; Murdock, N.; Bryant, W.S.; et al. Biodiversity of the Southeastern United States: Upland Terrestrial Communities; John Wiley \& Sons: New York, NY, USA, 1993; p. 400.

17. Miller, J.H. Pine Plantation Communities: How Do We Begin to Manage for Plant Diversity. In New Century: New Opportunities: Proceedings, 54th Annual Southern Weed Science Society Meeting, Biloxi, MS, USA, 22-24 January 2001; Southern Weed Science Society: Champaign, IL, USA, 2001; pp. 215-219.

18. Linder, E.T. Biodiversity and Southern Forests. In Southern Forest Science: Past, Present, and Future; Gen. Tech. Rep. SRS 75; U.S. Department of Agriculture, Forest Service, Southern Research Station: Asheville, NC, USA, 2004; Volume 25, pp. 303-306.

19. Hardt, R.A. Japanese honeysuckle: From "one of the best" to ruthless pest. Arnoldia USA 1986, 46, 27-34.

20. Schierenbeck, K.A. Japanese honeysuckle (Lonicera japonica) as an invasive species: History, ecology, and context. Crit. Rev. Plant Sci. 2004, 23, 391-400.

21. Liu, D.; Jiang, H.; Zhang, R.; He, K.S. Predicting the Spatial Distribution of Lonicera japonica, Based on Species Occurrence Data from Two Watersheds in Western Kentucky and Tennessee. In Proceedings of 17th Central Hardwood Forest Conference, Lexington, KY, USA, 5-7 April 2010; Fei, S., Lhotka, J.M., Stringer, J.W., Gottschalk, K.W., Miller, G.W., Eds.; U.S. 
Department of Agriculture, Forest Service, Northern Research Station: Lexington, KY, USA, 2011; pp. 418-424.

22. Leatherman, A.D. Ecological Life-History of Lonicera japonica Thunb. Ph.D. Thesis, University of Tennessee: Knoxville, TN, USA, 1955.

23. Schierenbeck, K.A. Comparative Ecological and Genetic Studies between a Native (Lonicera sempervirens L.) and an Introduced Congener (L. japonica Thunb.). Ph.D. Thesis, Washington State University: Pullman, WA, USA, 1992.

24. West, N.M.; Gibson, D.J.; Minchin, P.R. Microhabitat analysis of the invasive exotic liana Lonicera japonica Thunb. J. Torrey Bot. Soc. 2010, 137, 380-390.

25. Faulkner, J.L.; Clebsch, E.E.C.; Sanders, W.L. Use of prescribed burning for managing natural and historic resources in Chickamauga and Chattanooga National Military Park, USA. Environ. Manag. 1989, 13, 603-612.

26. Cain, M.D.; Wigley, T.B.; Reed, D.J. Prescribed fire effects on structure in uneven-aged stands of loblolly and shortleaf pines. Wildl. Soc. Bull. 1998, 26, 209-218.

27. Casper, B.B.; Jackson, R.B. Plant competition underground. Annu. Rev. Ecol. Syst. 1997, 28, 545-570.

28. Oosting, H.J.; Livingston, R.B. A resurvey of a loblolly pine community twenty-nine years after ground and crown fire. Bull. Torrey Bot. Club 1964, 91, 387-395.

29. Bell, D.J.; Forseth, I.N.; Teramura, A.H. Field water relations of three temperate vines. Oecologia 1988, 74, 537-545.

30. Yurkonis, K.A.; Meiners, S.J. Invasion impacts local species turnover in a successional system. Ecol. Lett. 2004, 7, 764-769.

31. Nyboer, R. Vegetation management guideline: Japanese honeysuckle (Lonicera japonica Thunb.). Nat. Areas J. 1992, 12, 217-218.

32. Thomas, L.K. The impact of three exotic plant species on a Potomac Island. Natl. Park Serv. Sci. Monogr. Ser. 1980, 13, 1-179.

33. Myster, R.W.; Pickett, S.T.A. Dynamics of associations between plants in ten old fields during 31 years of succession. J. Ecol. 1992, 80, 291-302.

34. Dillenburg, L.R.; Whigham, D.F.; Teramura, A.H.; Forseth, I.N. Effects of below- and aboveground competition from the vines Lonicera japonica and Parthenocissus quinquefolia on the growth of the tree host Liquidambar styraciflua. Oecologia 1993, 93, 48-54.

35. Thuiller, W.; Albert, C.; Araújo, M.B.; Berry, P.M.; Cabeza, M.; Guisan, A.; Hickler, T.; Midgley, G.F.; Paterson, J.; Schurr, F.M.; et al. Predicting global change impacts on plant species' distributions: Future challenges. Perspect. Plant Ecol. Evol. Syst. 2008, 9, 137-152.

36. Bradley, B.A.; Blumenthal, D.M.; Wilcove, D.S.; Ziska, L.H. Predicting plant invasions in an era of global change. Trends Ecol. Evol. 2010, 25, 310-318.

37. Bradley, B.A. Assessing ecosystem threats from global and regional change: Hierarchical modeling of risk to sagebrush ecosystems from climate change, land use and invasive species in Nevada, USA. Ecography 2010, 33, 198-208.

38. Westerling, A.L.; Hidalgo, H.G.; Cayan, D.R.; Swetnam, T.W. Warming and earlier spring increase western U.S. forest wildfire activity. Science 2006, 313, 940-943. 
39. Hansen, M.; Clevenger, A. The influence of disturbance and habitat on the presence of non-native plant species along transport corridors. Biol. Conserv. 2005, 125, 249-259.

40. USDA Agricultural productivity in the United States. Available online: http://www.ers.usda.gov/ Data/AgProductivity (accessed on 13 January 2011).

41. Rudis, V.A.; Gray, A.; McWilliams, W.; O’Brien, R.; Olson, C.; Oswalt, S.; Schulz, B. Regional Monitoring of Nonnative Plant Invasions with the Forest Inventory and Analysis Program. In Proceedings of the Sixth Annual FIA Symposium, Denver, CO, USA, 21-24 September 2006; McRoberts, R.E., Reams, G.A., Deusen, P.C.V., McWilliams, W.H., Eds.; Gen. Tech. Rep. WO-70; USDA Forest Service: Washington, DC, USA, 2006; pp. 49-64.

42. USDA (United States Department of Agriculture). FIA data and tools. Available online: http://fia.fs.fed.us/tools-data (accessed on 4 November 2010).

43. USDA (United States Department of Agriculture). Nonnative invasive plant data tool. Available online: http://srsfia2.fs.fed.us/data_center/index.shtml (accessed on 10 August 2011).

44. NOAA (United States Department of Agriculture). Climate maps of the United States. Temperature maps. Available online: http:/cdo.ncdc.noaa.gov/cgi-bin/climaps/climaps.pl (accessed on 15 June 2010).

45. Spittlehouse, D.L.; Stathers, R.J. Seedling Microclimate; Land Management Report; Ministry of Forests: Victoria, BC, Canada, 1990; pp. 28-36.

46. Jones, R.H.; McLeod, K.W. Shade tolerance in seedlings of Chinese tallow tree, American sycamore, and cherrybark oak. Bull. Torrey Bot. Club 1989, 116, 371-377.

47. Burns, J.H.; Miller, T.E. Invasion of Chinese tallow (Sapium sebiferum) in the Lake Jackson area, northern Florida. Am. Midl. Nat. 2004, 152, 410-417.

48. Pattison, R.R.; Mack, R.N. Potential distribution of the invasive tree Triadica sebifera (Euphorbiaceae) in the United States: Evaluating CLIMEX predictions with field trials. Glob. Chang. Biol. 2008, 14, 813-826.

49. Wills, C.; Condit, R.; Foster, R.B.; Hubbell, S.P. Strong density- and diversity-related effects help to maintain tree species diversity in a neotropical forest. Proc. Nat. Acad. Sci. USA 1997, 94, 1252-1257.

50. Filipescu, C.N.; Comeau, P.G. Competitive interactions between aspen and white spruce vary with stand age in boreal mixedwoods. For. Ecol. Manag. 2007, 247, 175-184.

51. Lombardo, K.; Fehmi, J.S.; Rice, K.J.; Laca, E.A. Nassella pulchra survival and water relations depend more on site productivity than on small-scale disturbance. Restor. Ecol. 2007, 15, 177-178.

52. Huebner, C.D.; Tobin, P.C. Invasibility of mature and 15-year-old deciduous forests by exotic plants. Plant Ecol. 2006, 186, 57-68.

53. Pyšek, P.; Jarošík, V.; Kučera, T. Patterns of invasion in temperate nature reserves. Biol. Conserv. 2002, 104, 13-24.

54. Overmars, K.P.; de Koning, G.H.J.; Veldkamp, A. Spatial autocorrelation in multi-scale land use models. Ecol. Model. 2003, 164, 257-270.

55. Gan, J.; Miller, J.H.; Wang, H.-H.; Taylor, J.W. Invasion of tallow tree into southern U.S. forests: Influencing factors and implications for mitigation. Can. J. For. Res. 2009, 39, 1346-1356. 
56. Martin, T.G.; Wintle, B.A.; Rhodes, J.R.; Kuhnert, P.M.; Field, S.A.; Low-Choy, S.J.; Tyre, A.J.; Possingham, H.P. Zero tolerance ecology: Improving ecological inference by modelling the source of zero observations. Ecol. Lett. 2005, 8, 1235-1246.

57. Liang, J.; Buongiorno, J.; Monserud, R.A.; Kruger, E.L.; Zhou, M. Effects of diversity of tree species and size on forest basal area growth, recruitment, and mortality. For. Ecol. Manag. 2007, 243, 116-127.

58. Agresti, A. An Introduction to Categorical Data Analysis, 2nd ed.; John Wiley \& Sons, Inc.: Hoboken, NJ, USA, 2007; p. 372.

59. Akaike, H. Information Theory and an Extension of the Maximum Likelihood Principle. In Second International Symposium on Information Theory; Kotz, S., Johnson, N.L., Eds.; Academia Kiado: Budapest, Hungary, 1973; pp. 267-281.

60. Hosmer, D.W.; Lemeshow, S. Applied Logistic Regression; John Wiley \& Sons, Inc.: New York, NY, USA, 2000; p. 392.

61. Bernstein, L.; Bosch, P.; Canziani, O.; Chen, Z.; Christ, R.; Davidson, O.; Hare, W.; Huq, S.; Karoly, D.; Kattsov, V.; et al. Climate Change 2007, the Fourth Assessment Report (AR4) of the United Nations Intergovernmental Panel on Climate Change (IPCC). In Proceedings of IPCC, UN, Valencia, Spain, 12-17 November 2007.

62. Lemke, D.; Hulme, P.E.; Brown, J.A.; Tadesse, W. Distribution modelling of Japanese honeysuckle (Lonicera japonica) invasion in the Cumberland Plateau and mountain region, USA. For. Ecol. Manag. 2012, 262, 139-149.

63. Beans, C.; Kilkenny, F.; Galloway, L. Climate suitability and human influences combined explain the range expansion of an invasive horticultural plant. Biol. Invasions 2012, doi:10.1007/s1053010012-10214-10530.

64. Woodward, F.I. Climate and Plant Distribution; Cambridge University Press: Cambridge, UK, 1987; pp. 174.

65. Richardson, D.M.; Wilgen, B.W.V. Invasive alien plants in South Africa: How well do we understand the ecological impacts. S. Afr. J. Sci. 2004, 100, 45-55.

66. Ibáñez, I.; Silander, J.A., Jr.; Wilson, A.M.; LaFleur, N.; Tanaka, N.; Tsuyama, I. Multivariate forecasts of potential distributions of incasive plant species. Ecol. Appl. 2009, 19, 359-375.

67. Daubenmire, R.F. Plants and Environment: A Textbook of Plant Autecology; John Wiley \& Sons: New York, NY, USA, 1974; p. 432.

68. Cain, M.D. Japanese honeysuckle in uneven-aged pine stands: Problems with natural pine regeneration. Proc. South. Weed Sci. Soc. 1992, 45, 264-269.

69. Smith, D.M.; Larson, B.C.; Kelty, M.J.; Ashton, P.M.S. The Practice of Silviculture: Applied Forest Ecology; John Wiley \& Sons, Inc: New York, NY, USA, 1997; p. 560.

70. Wang, Z.; Nyland, R.D. Changes in the condition and species composition of developing even-aged northern hardwood stands in central New York. North. J. Appl. For. 1996, 13, 189-194.

71. Surrette, S.B.; Brewer, J.S. Inferring relationships between native plant diversity and Lonicera japonica in upland forests in north Mississippi, USA. Appl. Veg. Sci. 2008, 11, 205-214.

72. Weber, J.S.; Gibson, K.D. Exotic plant species in old-growth forest in Indiana. Weed Sci. 2007, 55, 299-304. 
73. Barden, L.S.; Matthews, J.F. Change in abundance of honeysuckle (Lonicera japonica) and other ground flora after prescribed burning of a Piedmont pine forest. Castanea 1980, 45, 257-260.

74. Cacek, T. The National Park Service Integrated Pest Management Manual. In Identification, Biology, Management; National Park Services, U.S. Department of the Interior: Washington, DC, USA, 1998. Available online: http://www.nature.nps.gov/biology/ipm/manual/fleas.cfm (accessed on 1 May 2012).

75. Kush, J.S.; Meldahl, R.S.; Boyer, W.D. Understory Plant Community Response to Season of Burn in Natural Longleaf Pine Forests. In Proceedings of Tall Timbers Fire Ecology Conference Proceedings, Boston, MA, USA, 5-9 November 2000; Moser, W.K., Moser, C.E., Eds.; Tall Timbers Research Station: Tallahassee, FL, USA, 2000; pp. 32-39.

76. Brewer, J.S.; Menzel, T. A method for evaluating outcomes of restoration when no reference sites exist. Restor. Ecol. 2009, 17, 4-11.

77. Moreno, J.M.; Oechel, W.C. Demography of Adenostoma fasciculatum after fires of different intensities in southern California chaparral. Oecologia 1993, 96, 95-101.

78. Higgins, S.I.; Lavorel, S.; Revilla, E. Estimating plant migration rates under habitat loss and fragmentation. Oikos 2003, 101, 354-366.

79. Holle, B.V.; Simberloff, D. Ecological resistance to biological invasion overwhelmed by propagule pressure. Ecology 2005, 86, 3212-3218.

80. Kuhman, T.; Pearson, S.; Turner, M. Effects of land-use history and the contemporary landscape on non-native plant invasion at local and regional scales in the forest-dominated southern Appalachians. Landsc. Ecol. 2010, 25, 1433-1445.

81. Roberts, H.A. Periodicity of seedling emergence and seed survival in some Umbelliferae. J. Appl. Ecol. 1979, 16, 195-201.

82. Pyšek, P.; Jarošík, V.; Hulme, P.E.; Kühn, I.; Wild, J.; Arianoutsou, M.; Bacher, S.; Chiron, F.; Didžiulis, V.; Essl, F.; et al. Disentangling the role of environmental and human pressures on biological invasions across Europe. Proc. Natl. Acad. Sci. USA 2010, 107, 12157-12162.

83. Baars, R.; Kelly, D.; Sparrow, A.D. Liane distribution within native forest remnants in two regions of the South Island, New Zealand. New Zeal. J. Ecol. 1998, 22, 71-85.

84. Dukes, J.S.; Mooney, H.A. Does global change increase the success of biological invaders? Trends Ecol. Evol. 1999, 14, 135-139.

85. Richardson, D.M.; Iponga, D.M.; Roura-Pascual, N.; Krug, R.M.; Milton, S.J.; Hughes, G.O.; Thuiller, W. Accommodating scenarios of climate change and management in modelling the distribution of the invasive tree Schinus molle in South Africa. Ecography 2010, 33, 1049-1061.

86. Walther, G.-R.; Roques, A.; Hulme, P.E.; Sykes, M.T.; Pyšek, P.; Kühn, I.; Zobel, M.; Bacher, S.; Botta-Dukát, Z.; Bugmann, H.; et al. Alien species in a warmer world: Risks and opportunities. Trends Ecol. Evol. 2009, 24, 686-693.

87. Peterson, A.T. Predicting the geography of species' invasions via ecological niche modeling. Q. Rev. Biol. 2003, 78, 419-433.

88. Ebeling, S.K.; Welk, E.; Auge, H.; Bruelheide, H. Predicting the spread of an invasive plant: Combining experiments and ecological niche model. Ecography 2008, 31, 709-719.

89. Soberón, J. Grinnellian and Eltonian niches and geographic distributions of species. Ecol. Lett. 2007, 10, 1115-1123. 
90. Rose, N.-A.; Burton, P.J. Using bioclimatic envelopes to identify temporal corridors in support of conservation planning in a changing climate. For. Ecol. Manag. 2009, 258, S64-S74.

(C) 2012 by the authors; licensee MDPI, Basel, Switzerland. This article is an open access article distributed under the terms and conditions of the Creative Commons Attribution license (http://creativecommons.org/licenses/by/3.0/). 